\title{
HOW CHICK-LIT AFFECTS WOMEN THROUGH ROMANCE FORMULA: A STUDY CASE ON LAUREN WEISBERGER'S DEVIL WEARS PRADA AND JANE GREEN'S JEMIMA JONES
}

\author{
Mia Fitria Agustina \\ Jenderal Soedirman University
}

\begin{abstract}
Women have very unique characteristics. They are far different from men. Therefore, women needs are also different from men needs including the need to read. Men tend to read adventure works. The adventure works fulfill man's need to taste the adventure as the hero-individual or group in adventures works is able to overcome obstacles and dangers to accomplish some important and moral mission. In another hand, women prefer to read romance ones. It is because romance formula provides what women desired. Moreover romance works are the feminine equivalent of the adventure stories. Furthermore, chick-lits, the women best friend, is one of the romance works. As it is used romance formula, chick-lits has ability to provide women's desire. It transforms the need, and interprets it through the narrative of chick-lits. That is why, because to find out how the interpretation of the works is an fascinating challenge, this paper tries to see the connection between chick-lits romance formula and how it affects the readers, the women.
\end{abstract}

Key words: chick-lits, women, romance formula, and the needs

\section{BACKGROUD}

Men are from Mars, Women are from Venus is a book written by John Gray and published in May 1992. This book title becomes a very famous quotation to express how women and men are different as those genders have different way not only to communicate and value each other but also to fulfill their emotional needs. Women tend to express their emotional more than men because of culture. The 
culture lets women state what they feel, so when they are sad, they will cry; when they are happy, they will laugh. That is why, the way in expressing women feeling becomes a very interesting thing to be discussed further. Besides, this way to express the feeling makes them need someone or something, for example, when women feel sad, they tend to seek friends to share. Furthermore, these friends can be in the form of food such as chocolates, dolls such as teddy bear or books such as chic-lits. Based on this, it cannot be denied that chick-lit comes as the answers of women's need as the books which women need have to embrace women and treat women as their own best friend.

Chick-lits is a genre of fiction within women's fiction written for females which generally deals with the issues of modern women humorously and lightheartedly (http://www.goodreads.com/genres/chick-lit). From this definition, it can be seen that the setting of chick-lits is in the modern era. It is chosen as living in the modern world, especially for women, causes women deal with obstacles which are far different from the previous era. For example, in the modern era, women have freedom to decide when they get married. This is different from previous era as married is a kind of obligation for women. However, they face many other obstacles such as dealing with the work they have, or dealing with their own selves. Chick lit is told in a more confiding, personal tone, so it is like having a best friend tell you about her life or watching various characters go through things that you have gone through yourself, or witnessed others going through (http://chicklitbooks.com/what-is-chick-lit/). Therefore, the definition of chick-lit proves chick-lit as women's best friend which also emphasizes one more time that this genre is for women. The tone and the way chick-lit involves women are the strength to influence women to face their world. Finally, it is undeniable that chicklit is produced to fulfill women need especially their emotional need to deal with the life they live in.

Based on the explanation above about chick lit, it is motivating to see deeper the way on how this chic-lit affect their readers who are almost all women. There are many things of chick-lit which affect the readers. Moreover, to make this writing more focus, the writer is going to relate the way how chick-lit affect women through its formula. Besides, in this paper there will be only two chik-lits discussed. Those are Devil Wears Prada by Lauren Weisberger and Jemima Jones By Jane Green. 


\section{The Devil Wears Prada}

The Devil Wears Prada (2003) is a best-selling novel by Lauren Weisberger. The story mainly talks about a young woman who freshly graduated from college. She is hired as a personal assistant to a powerful fashion magazine editor. Her job becomes her enemy as she struggles to keep up with her boss's demanding orders and requests. Moreover, it was greatly successful novel since it was six months on the New York Times bestseller list. Therefore, it is not a surprise when the movie (2006) played by Meryl Streep, Anne Hathaway, and Emily Blunt is also successful.

The novel begins with its main character, Andrea Sachs, stuck in midtown Manhattan traffic, trying to remember how to use a manual transmission. She has picked up the Porsche that belongs to her boss, Runway magazine editor Miranda Priestly, from a shop and must return it to Miranda's apartment in time for Miranda's family is going to go out to the Hamptons for the weekend. While she is attempting to do this, Miranda calls on her cell phone and screams her for not doing her job properly. She also tells her to pick up her pet French bulldog from the veterinarian's office. Trying to do all of the orders, Andrea ruins some of the expensive designer clothing she is wearing. She also wishes Miranda would die. But if that did happen, she reminds herself, she would lose the pleasure of killing Miranda herself.

The next chapter is about how Andrea got the job. She is hired as Miranda's junior assistant. Miranda is a classic "boss from hell." This is because Miranda rarely gives enough information or time to do her demands. Moreover, she routinely accuses Andrea when she is failed doing Miranda's orders. Miranda makes Andrea do whatever Miranda wants. Furthermore, Miranda thinks it is fine to order Andrea to get Starbucks coffee or a steak lunch from Smith and Wollensky. Also, it is fine, according to Miranda, not to drink or to eat what she has ordered as the meal and the drink have gotten too cold for her.

Finally, Andrea fits in Runway. Moreover, she meets Christian Collinsworth, a Yale graduate who has been identified as the hot up-and-coming writer of his and her generation. They become attracted to each other, complicating her relationship with Alex (Andrea's boyfriend). Her job begins to affect Andrea health; she starts to lose weight because she cannot make herself eat. Besides, Andrea begins to doubt the true value of her job, as it is, primarily, encouraging the woman who makes teenagers all over America hate themselves (for being fat). 
However, she keeps thinking that it will all be worthwhile when she gets a job at The New Yorker. Moreover, since Andrea is so busy, she only has a few time to be spent with Alex and Lily (her best friend), who is increasingly turning to alcohol and picking up dubious men in order to relieve the pressures of graduate school. Her relationship with her family also begins to suffer. Her parents complain she is not making time to visit her older sister, who is expecting her first child. In the end, Andrea finally realizes that her family and friends are more important than her job as she realizes that she is becoming more and more like Miranda.

\section{Jemima Jones}

Jemima is an editor at the Kilburn Herald. She is a very fat girl, and she is $109 \mathrm{~kg}$. However, she keeps eating. This happens because she feels isolated in her own place to work as everybody in her work place treats her like a maid. What make her hang on is Ben Williams. Jemima loves Ben, but she knows well that it is impossible to win his heart. Ben is so handsome and popular. For Jemima, it is like waiting for "Godot" as Jemima is sure that her appearance drives her away from Mr. Right, Ben.

Jemima life starts to change when she meets Brad through internet. Brad is a sexy man from Los Angeles. He insists to meet Jemima. This is a problem since Jemima sends Brad her re-touch picture. On the picture, Jemima is a thin woman. As Brad asks Jemima again and again to come to Los Angeles, Jemima starts to figure out the way out. That is why Jemima tries hard to be as what Brad sees on the picture. She starts to go to the gym and eats healthy food. She is so obsessed to be thin. Finally, she is ten as before she was sixteen. And this size, ten, gives Jemima courage to go to Los Angeles to meet Brad.

Finally, after having a perfect body, Jemima visits Brad in LA. The plan is she is going to stay in LA for two weeks, but these two weeks become three months. This indicates that the relationship between Jemima and Brad work smoothly. However, unintentionally, Jemima reveals Brad secret. And this revelation, later on, destroys Jemima and Brad relationship. Therefore, because of Brad, Jemima is so devastated. Lucky for her, she meets her best friend, Ben, accidently in LA. Ben is the only cure Jemima can think of. In LA, Jemima sees Ben several times, and knows that her heart still belongs to Ben. Finally, Jemima realizes that it is Ben, the one, who will heal Jemima broken-hearted. 
At the end of this story, Jemima Jones is no longer obsessed to be thin. She is twelve. She thinks that it is the best for her. She also believes that her dream about Mr. Right is not only dream anymore. The Mr. Right is with Jemima now, and he can accept Jemima as she is. It does not need to be the thin girl to be with Ben. That is why, this last statement changes Jemima and sets Jemima free to be what she always wants to be.

\section{ROMACE FORMULA}

Formula, according Cawelty (1977:5) is a structure of narrative or dramatic conventions employed in a great number of individual works. The reason why those works employ formula is because the purpose of the works is helping the readers to enjoy and to escape. To enjoy is about the way given by the author to make the readers feel better after they read the works as the life is so hard. Readers need a mean to help them to be happy, and the mean is the formula. While, to escape is about feeling free from the real life in a few moment. As life is so hard, the readers want to avoid it by reading the works. When they read, they feel that the world is on their hands. They can posses the world and do what they want on it. That is why, it cannot be denied that formula has a very important role in influencing the readers.

To achieve the purpose of the works, the formula creates its own world which we become familiar by repetition (Cawelty, 1977:10). This repetition, finally, divides the formula into five, namely, Adventure, Romance, Mystery, Melodrama, and Alien Beings or States. Adventure is about the hero-individual or groupovercoming obstacles and dangers and accomplishing some important and moral mission. While romance is about the feminine which is equivalent with the adventure stories. Mystery is about the investigation and discovery of hidden secret which leads to some benefit for the character(s) with whom the reader identifies. Melodrama is about designating a certain kind of literary structure. And the last is Alien Beings or States which is about stories dealing with alien beings and states.

Based on the definition mentioned, it can be seen that chik-lit is close to romance since women enjoy romance more than adventure. By reading works with romance formula women can get enjoyment to escape from their real world. Besides, chiclit employs four characteristics of romance formula. Those characteristics are: 
1. it stars a female

2. its organizing action is the development of a love relationship, usually between a man and a woman

3. the love in the story is capable to overcome all obstacles and difficulties

4. and the career girl, the heroin of the story, rejects love in favor of wealth or fame

\section{DISCUSSION}

As it is explained before, there are four characteristics of romance formula. Those are it stars a female; its organizing action is the development of a love relationship, usually between a man and a woman; the love in the story is capable to overcome all obstacles and difficulties; and the career girl, the heroin of the story, rejects love in favor of wealth or fame. To begin with, the first characteristic is it stars a female (Cawelty, 1977:41). In Devil Wears Prada, the star is Andrea Sach. Andrea Sachs is a small-town girl fresh out of college. She gets a job which is wanted by million girls as "a millions girls would die for." She works as Miranda Priestly's assistant, and because Miranda is a successful editor of Runway magazine, it can be imagined how hard her works can be. Meanwhile in Jemima Jones, the star is Jemima Jones. She is overweight about one hundred pounds overweight. She is also treated like a maid by her thin and social-climbing roommates, and lorded over by the beautiful Geraldine. Therefore, Jemima finds that her only consolation is food. Finally, seeing those stars, the first characteristics of romance is fulfilled by these chick-lit as Andrea Sach and Jemima Jones are the female stars on those chick-lit.

After talking about the first characteristics which is it stars a female, the second characteristic is its organizing action is the development of a love relationship, usually between a man and a woman (Cawelty, 1977:41). In Jemima Jones, love seems to be the main problem. It happens as Jemima is a fat girl. She struggles to be thin as she is addicted on food. She wants to be thin as she thinks if she is thin, she is capable to get love she wants. God, I wish I were thin. I wish I were thin, gorgeous, and could get any man I want. You probably think I'm crazy, I mean here I am, sitting at work on my own with a massive double-decker club sandwich in front of me, but I'm allowed to dream aren't I? This is part of the novel which says that Jemima gets problem of love as she is not thin. That is why, the rest of the novel talks about how Jemima conquers her food addict to win the love she always wants. 
Moreover, this food addict consumes her brain and becomes a spell saying that love will come to her when she is thin.

I lie there and spin out an elaborate fantasy about what I would wear if I were thin. I would have my hair cut into a super trendy shaggy style, and perhaps, if I dared, would have a few blonde highlights, just at the front.

Even first thing in the morning I will look gorgeous. With no make-up and tousled hair, I imagine meeting Mr. Perfect, and curling up in an armchair with my long, glowing legs, my bony knees, and naturally he will be head over heels in love with me.

Seeing this quotation from the novel, it can be seen that the ultimate goal of Jemima is trying to be thin to win Mr. Perfect's heart. She always thinks that to be thin is the solver for her. Then, she learns how to deal with her life that is not always perfect. Even though she is successful to be thin, she cannot denied that it cannot answer what she expects about life. And to make it short, Mr. Perfect that she always dreams of is not someone who is like a model that she always sees on every magazine she is collected but someone who can accept her for whatever she is and someone who can support her all the way she has to be through. This story shows how the development of a love relationship between Jemima and several men that she has met becomes the main part in developing the action of the story. It is not too different from The Devil Wears Prada (2003) by Lauren Weisberger. In this novel, the main character, Andrea Sach, also experiences love relationship development. Before she gets the job in Runway, she has a very good relationship with her boyfriend named Alex. However, it is the job which makes her be a part with her boyfriend. Besides, another character named Christian Collinsworth causes her relationship worse. His present causes Andrea get more problems related to her relationship. This shows how her love relationship develops. Finally, in summary, these stories match with the second characteristic of the formula which is the organizing action is the development of a love relationship, usually between a man and a woman.

The third characteristic is love triumphant and permanent overcomes all obstacles and difficulties (Cawelty, 1977:41-42). In Jemima Jones, having Ben becomes Jemima strength to get many things that once she does not dare to achieve. As it is mentioned before the thought that thin becomes the only way for 
her eats her brain. She thinks that if she is not thin she has no hope. However, to have Ben right in her side helps Jemima to reach all she never dreams of. She gets 
doing Miranda's orders. These are far beyond her imagination about working in Runaway. What she wants is to be a journalist. It means that she uses her skill something that she earns to get through her educational background. However, the reality is not as beautiful as she has imagined before. She has to choose between stay or go. Finally she chooses to go. Moreover, she wants to be loved as the way before. Her lover, Alex, leaves her as she is getting famous and wealthy. Because of her job which provides her in any girl dream of in cosmopolitan world, she changes. This causes her loses her beloved. Though it is late to realize that finally she learns to leave wealth and fame and she is confident enough to be herself again and ready to be loved as whatever she is. In conclusion, the career girl, Andrea, who rejects love in favor of wealth or fame, and discovers that love alone is fully satisfying are in line with this fourth characteristics. This is also happens to Jemima. She refuses to be obsessed to be thin anymore, as she knows that she can be accepted as whatever she is. She stops to be ten and decides to be twelve. She is also refuses to accept Brad's offer to stay with him in Los Angeles, although staying with Brad guarantees her to be more famous and wealthy. Therefore, it can be concluded that the fourth characteristic is also applied by chick-list which puts it as women's best friend and has power to affect those women.

\section{CONCLUSION}

There are four characteristics of romance, namely, it stars a female; its organizing action is the development of a love relationship, usually between a man and a woman; that of love triumphant and permanent, overcoming all obstacles and difficulties; and that of the career girl who rejects love in favor of wealth or fame, only to discover that love alone is fully satisfying. All of those characteristics, the romance formula, as it has been discussed above, show that those can affect women as the characteristics represent women themselves. The female as the star is the first characteristic which proves that chick-lit is close to women. Through this star, women can take a part in the story. They feel that the stars are themselves. They experience what the star deals with. It causes them feel closer to chick-lit. While, the love relationship cannot be denied that it is the most important part of women. Love story is women life. Using loves story as the main issue in the story helps chick-lit to be closer to women. Somehow it also affects women through their unconsciousness mind. It cannot be argued further that the influences cause 
women laugh or cry during their reading experience. Therefore, this, one more time, shows that chick-lit has power over women. Besides, love can win all is what 
Journal of English and Education, Vol. 5 No.1 - Juni 2011 